\title{
SIFAT DAN FUNGSI HAK PATEN
}

\author{
Desi Ratnasari \\ 155100016 \\ Fakultas Komputer, 448757183 \\ desiratnasarii.student@umitra.ac.id
}

\begin{abstract}
Pengertian kata paten, berasal dari bahasa inggris patent, yang awalnya berasal dari kata patere yang berarti membuka diri (untuk pemeriksaan publik), dan juga berasal dari istilah letters patent, yaitu surat keputusan yang dikeluarkan kerajaan yang memberikan hak eksklusif kepada individu dan pelaku bisnis tertentu. Hak Paten adalah hak eksklusif yang diberikan oleh Negara kepada penemu atas hasil penemuannya di bidang teknologi, yang untuk selama waktu tertentu melaksanakan sendiri Invensinya tersebut atau memberikan persetujuannya kepada pihak lain untuk melaksanakannya.
\end{abstract}

Kata Kunci : Sifat Dan Fungsi Hak Paten 


\section{A. INTRODUCTION}

\section{Definisi}

Kata paten, diambil dari bahasa Inggris yaitu patent, yang awalnya berasal dari kata patere yang artinya membuka diri (untuk pemeriksaan publik), dan juga berasal dari istilah letters patent, yaitu surat keputusan yang dikeluarkan kerajaan yang memberikan hak eksklusif kepada individu dan pelaku bisnis tertentu.

Definisi kata paten itu sendiri, konsep paten mendorong inventor untuk membuka pengetahuan demi kemajuan masyarakat dan sebagai gantinya, inventor mendapat hak eksklusif selama periode tertentu. Mengingat pemberian paten tidak mengatur siapa yang harus melakukan invensi yang dipatenkan, sistem paten tidak dianggap sebagai hak monopoli.

\section{Sifat Dan Fungsi Hak Paten}

Sifat dari hak paten, yaitu:

1. Memberikan Perlindungan Hukum atas setiap karya intelektual di bidang teknologi, sehingga terjamin hak kepemilikan pemegang paten.

2. Mewujudkan iklim yang lebih baik bagi kegiatan invensi di bidang teknologi, sebab teknologi memiliki peranan yang sangat penting dalam pembangunan nasional secara umum dan khususnya di sektor industri,

3. Memberikan insentif bagi para inventor dalam melakukan inovasi baru melalui hak eksklusif atas invensi yang dihasilkannya.

4. Sarana pengungkapan terbuka mengenai informasi teknologi terkini yang dipatenkan, sehingga masyarakat dapat 
$\begin{array}{lr}\text { memanfaatkannya } & \text { untuk } \\ \text { penyempurnaan } & \text { dan }\end{array}$

pengembangan teknologi lebih lanjut.

Fungsi paten:

1. Hak ekslusif

2. Kepastian hukum

3. Insentif terhadap suatu kreasi teknologi

4. Posisi pasar yang kuat

5. Meningkatkan daya saing

6. Kesempatan lisensi

7. Mendorong investasi (FDI)

8. Katalis transfer teknologi

9. Strategi perencanaan perdagangan dan industry

\section{B. CONCLUSION}

Kesimpulan

Tujuan dari hak paten, yaitu:

1. Memberikan Perlindungan Hukum atas setiap karya intelektual di bidang teknologi, sehingga terjamin hak kepemilikan pemegang paten.

2. Mewujudkan iklim yang lebih baik bagi kegiatan invensi di bidang teknologi, sebab teknologi memiliki peranan yang sangat penting dalam pembangunan nasional secara umum dan khususnya di sektor industri,

3. Memberikan insentif bagi para inventor dalam melakukan inovasi baru melalui hak eksklusif atas invensi yang dihasilkannya.

4. Sarana pengungkapan terbuka mengenai informasi teknologi terkini yang dipatenkan, sehingga masyarakat dapat memanfaatkannya untuk penyempurnaan dan pengembangan teknologi lebih lanjut. 


\section{ACKNOWLEDGEMENT}

University Of Indonesia

University Of Mitra Indonesia

Telkom University

University Of Mellbourne

Saitama University

\section{REFERENCE (Based ISO 690)}

[1] A. S. Putra And O. M. Febriani, "Knowledge Management Online Application In Pdam Lampung Province," In Prosiding International Conference On Information 
Technology And Business (Icitb), 2018, Pp. 181-187.

[2] A. S. Putra, O. M. Febriani, And B. Bachry, "Implementasi Genetic Fuzzy System Untuk Mengidentifikasi Hasil Curian Kendaraan Bermotor Di Polda Lampung," J. Sist. Inf. Dan Manaj. Basis Data, Vol. 1, No. 1, Pp. 21-30, 2018.

[3] O. M. Febriani And A. S. Putra, "Sistem Informasi Monitoring Inventori Barang Pada Balai Riset Standardisasi Industri Bandar Lampung," J. Inform., Vol. 13, No. 1, Pp. 90-98, 2014.

[4] Putra, Arie Setya. "2018 Artikel Struktur Data, Audit Dan Jaringan Komputer." (2018).

[5] Putra, A. S. (2018, July 17). Paperplain Fundamental Create Application With Borland Delphi 7.0 University Of Mitra Indonesia. Retrieved From Osf.Io/Pbrn9.

\section{E. REFERENCE (Based APA)}

Putra, A. S., Aryanti, D. R., \& Hartati, I. (2018, November). Metode SAW (Simple Additive Weighting) sebagai Sistem Pendukung Keputusan Guru Berprestasi (Studi Kasus: SMK Global Surya). In Prosiding Seminar Nasional Darmajaya (Vol. 1, No. 1, pp. 85-97).
Sari, D. P., Febriani, O. M., \& Putra, A. S. (2018, November). Perancangan Sistem Informasi SDM Berprestasi pada SD Global Surya. In Prosiding Seminar Nasional Darmajaya (Vol. 1, No. 1, pp. 289-294).

Putra, A. S. (2018). Paperplain: Execution Fundamental Create Application With Borland Delphi 7.0 University Of Mitra Indonesia.

Putra, A. S., Sukri, H., \& Zuhri, K. Sistem Monitoring Realtime Jaringan Irigasi Desa (JIDES) Dengan Konsep Jaringan Sensor Nirkabel. IJEIS (Indonesian Journal of Electronics and Instrumentation Systems), 8(2), 221232.

Darmawan, A., Yuliawati, D., Marcella, O., \& Firmandala, R. (2016). Sistem Absensi dan Pelaporan Berbasis Fingerprint dan SMS Gateway. EXPLORE, 7(1).

Febriani, O. M., Wahyuni, T., \& Yusuf, S. (2017). DESIGN OF WEBSITE-BASED INFORMATION SYSTEM FOR EDOCUMENT ADMINISTRASI IN THE COMMUNITY SERVICE UNIT (A Case Study at Rajabasa District). INTERNATIONAL JOURNAL OF COMPUTERS \& TECHNOLOGY, 16(7), 7010-7020.

Febriani, O. M., \& Wahyuni, T. (2017, October). PERANCANGAN SISTEM E-DOCUMENT ADMINISTRASI LOGBOOK PENELITIAN PADA UNIT LAYANAN DI BANDAR LAMPUNG. In Prosiding Seminar 
Nasional Darmajaya (Vol. 1, No. 1, pp. 187-194).

Febriani, O. M., \& Permadi, A. B. (2017). Implementasi Sistem Aplikasi Data Bimbingan dan Pelanggaran Siswa pada Sekolah Menengah Atas di Lampung Tengah dengan Metode Analisis dan Desain Sistem Terdistribusi (SSAD). EXPERT, 7(1).

Febriani, O. M., \& Ambarwati, L. (2015). PERANCANGAN APLIKASI PENGOLAHAN DATA PENJUALAN UKM KELANTING KHAS TELO DESA SIDOHARJO KECAMATAN JATI AGUNG KABUPATEN LAMPUNG SELATAN. Jurnal Teknologi Informasi dan Bisnis Pengabdian Masyarakat Darmajaya, 1(1), 77-95.

Febriani, O. M. (2015). Rancang Bangun Aplikasi Ecommercemenggunakan Freewebstore pada UKM Kelanting di Desa Sidoharjo Lampung Selatan. Prosiding Sembistek 2014, 1(02), 446-458. 